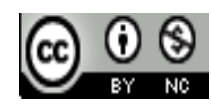

Jurnal Terapan Manajemen dan Bisnis is licensed under

A Creative Commons Attribution-NonCommercial 4.0 International License.

\title{
THE INFLUENCE OF EWOM THROUGH INSTAGRAM SOCIAL MEDIA ON ONLINE PURCHASE INTENTION OF PRODUCTS: STUDY IN THE CITY OF BATAM
}

\author{
Catheline $^{1)}$, Didi Sundiman ${ }^{2)}$ \\ 1) Universitas Universal, Batam, Indonesia \\ E-mail: catheline67@gmail.com \\ 2) Universitas Universal, Batam, Indonesia \\ E-mail: sundimand@gmail.com
}

\begin{abstract}
In general, this study aims to determine the effect of eWOM through social media Instagram on the purchase intention of products online in Batam City. This study uses a quantitative approach. The sample in this study amounted to 113 respondents who were users of social media Instagram. This research instrument using a questionnaire and analyzed using techniques Structural Equation Modeling (SEM) with the help of the SmartPLS 2.0 program. The results of this study indicate that trust, informational influence, moral obligation have significant involvement in eWOM, but the altruism variable does not have a significant effect on eWOM through social media Instagram and eWOM through social media Instagram has a strong influence on purchase intention of products online in Batam City. Based on the results of this study, it can be concluded that the exchange of information through eWOM can lead to consumer buying interest.
\end{abstract}

Keywords: Purchase Intention; eWOM; eWOM Behavior; Instagram Social Media

\section{Introduction}

The development of increasingly sophisticated information technology enables consumers to access the internet to obtain information anywhere and anytime. With this flexibility, consumers take advantage of social media starting from participating, sharing information on social media networks, one of which is Instagram.

Widespread use of the internet globally has gradually become an effective platform for a company to promote its products or services to potential consumers. Currently, many companies from various industries are actively offering social media to find new customers and maintain good relationships with existing customers (Kunja \& GVRK, 2018).

Word of mouth (WOM) is a general communication that plays an active role in providing an effect on consumer behavior in shopping and making behavior the desire to buy (Farzin \& Fattahi, 2018). Advances in technology in the field of communication and information have led to the development of WOM into eWOM (electronic Word of Mouth), which is one of the initial factors in the formation of consumer behavior in purchasing decisions. 
One of the goals of the company to create and market products is to attract consumer buying interest because purchases usually begin with an interest in a product. There are many ways that business people do to attract consumers to buy in order to increase sales. Understanding consumers of their needs and wants are not easy, for that sellers need to understand the various factors that attract or attract consumers in buying a product.

The desire of consumers for a product such as online business trends on Instagram must be well translated with interesting content so that the marketed product can be positively received by consumers. One of the factors that can influence a person's purchase intention is related to feelings and emotions, if consumers feel satisfaction in buying a product, it can also strengthen buying interest. It is not surprising that the purchase interest within consumers is very important in business marketing activities because purchase interest is a consumer behavior that underlies the purchase decision to be made.

The role of social media is important in purchasing decisions by providing repeated feedback to friends during, before, and after purchase by providing a safe online source for transactions through this disintermediation. Social media is currently getting a lot of attention from the public, such as researchers, academics, and practitioners (Farzin \& Fattahi, 2018).

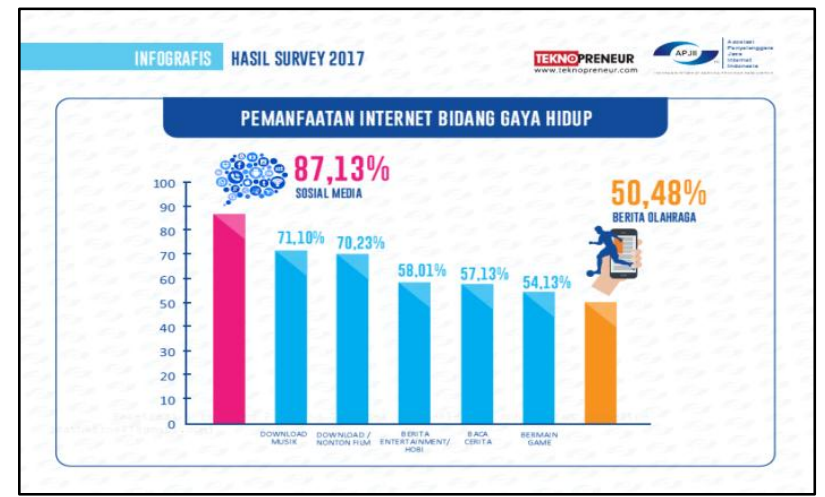

Fig. 1 Results of the 2017 Survey regarding the Use of the Internet in the Lifestyle Sector Source: www.apjii.or.id

Through the results of the 2017 APJII survey, the use of the internet in the lifestyle sector used by Indonesians with a percentage of $87.13 \%$ is social media. (APJII, 2017). One of the rampant social media today is Instagram. The development of Instagram social media is quite attractive to its users.

The launch of Instagram in 2010 was the latest breakthrough in the photo and videobased social media which is a phenomenal one until now with the addition of certain features such as tags and location information. Instagram is one of the most popular social media among young people today. Indonesia is the country with the largest Instagram users in the Asia Pacific. Of the 700 monthly active users, aka Monthly Active User (MAU), which Instagram has earned globally, 45 million of them come from Indonesia. The figure of 45 million MAU shows a significant increase when compared to January 2016 when at that time the MAU for Instagram in Indonesia was only 22 million. So that business people can maximize the benefits of Instagram (Bohang, 2017). 


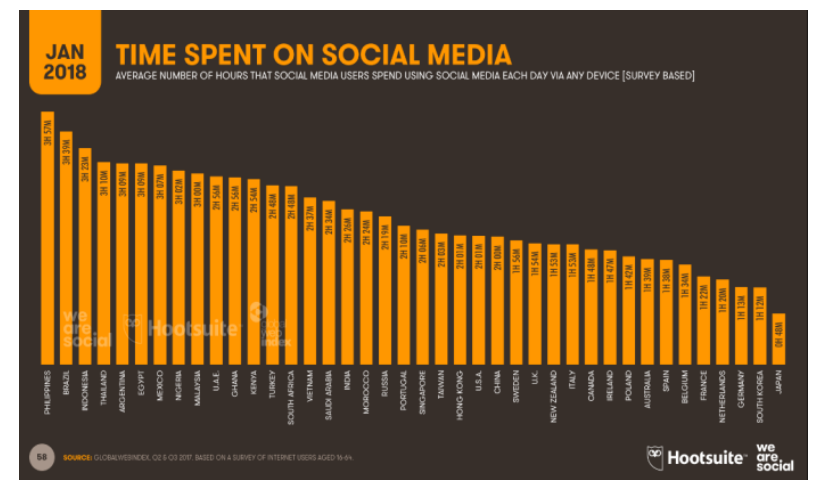

Fig. 2 Global Digital Report 2018

Source: wearesocial.com

Research from We Are Social explains that from such a large number of users, Indonesia ranks among the highest in the world with a duration of social media use of 3 hours 23 minutes. This duration when compared to the total average internet usage of Indonesians, Indonesians allocate nearly $30 \%$ of their time for social media. (Kemp, 2018). So that the more the development of Instagram in Indonesia, the more the character of the Instagram user community. Apart from ordinary users, some use it as a business medium. The eWOM communication formed on Instagram social media allows users to share information, trends, and experiences of using a product as well as the use of doing business by selling products online. The public sees interesting content on Instagram, it will create curiosity and arouse desire and interest to be able to buy products that are presented in some content on Instagram social media.

Online product business is facilitated by the presence of delivery services such as JNE, J\&T, TIKI, and Post Offices so that consumers do not worry about products that reach consumers. The increasing trend of online shopping in society, of course, affects courier service revenues. Seeing the phenomenon of increasing online shopping trends, both JNE, JNE, J\&T, TIKI, and Post Office couriers continue to improve their courier service facilities. JNE by opening 6,800 branches consisting of outlets, counters, and sub-agents spread throughout Indonesia, and the number of these networks will increase to reach areas where there are no JNE branches, targeting network growth of around $10 \%-15 \%$. Similar to J\&T, Robin Lo, CEO of PT. Global Jet Express, which sees J\&T Express's main revenue is still dominated by online shopping, around $60 \%$. During the three years in the logistics business, J\&T focused on online product package delivery with business growth than tripled compared to last year. During the establishment of the logistics business, J\&T has 2,000 branches with the hope that by the end of 2018 there will be 4,000 J\&T branches(Batam news, 2018).

Online business transactions in Batam occupy the first position in Indonesia so that many shipments from Batam are delayed 2 times longer due to overload, especially during the Eid, cancelation, New Year, and peak at the beginning of school opening (Batam news, 2018).

The eWOM variable in the research of Miland Farzin and Majid Fattahi (2018) with the title eWOM through Social Networking sites and impact on Purchase Intention and brand image in Iran states that eWOM has a significant effect on Purchase Intention. However, the results of research conducted by Omer Torlak, Behcet Yalin Ozkara, Muhammet Ali Tiltay, Hakan Cengiz, and Mehmet Fatih Dulger (2014) with the research title The Effect of eWOM on Brand Image and Purchase Intention an Application Concerning Cell Phone Brands for Youth Consumers in Turkey states that eWOM on purchase intention does not show positive 
results or has no effect. This is because the results come from a sample aimed at students who are at Turkish Universities who have different cultures and geographic locations.

This research will replicate the model used by Milad Farzin and Majid Fattah in 2018 in Iran but in a different location. The location studied by the researcher is Batam City with a model replication to determine whether there is an effect of eWOM through social media Instagram on Purchase Intention.

Based on this background, the researcher intends to conduct a study entitled "The Effect of e-WOM through Social Media Instagram on Purchase Intention of Products Online in Batam City". The problem examined in this study is whether (electronic Word of Mouth) eWOM through social media Instagram has a significant effect on Purchase Intention of products online in Batam City? This research aims to determine the influence of e-WOM through Instagram Social Media on Purchase Intention of Products Online in Batam City.

\section{Literature Review}

A. The Influence of Trust, Informational Influence, Altruism, Moral Obligation on eWOM

Trust has an important role in attracting people's attention to exchange information, judgments, and views about a product or brand (Huang, Hsiao, \& Chen, 2012; Ridings, Gefen, \& Arinze, 2002). Consumers see user-generated content as a more appropriate and reliable source of information and knowledge about products and brands than those generated by marketers. The content communicated through the promotional mix traditionally in industrial advertising (S.-C. Chu \& Kim, 2011; Mangold \& Faulds, 2009) so this conclusion leads to a Hypothesis;

H1: "Trust from consumers as social media users have a significant effect on eWOM on social media"

Furthermore, consumers can actively seek opinions from friends through social media. This kind of behavior is related to social influence, where social media users see followers they are an important source of product and brand information (Muk, 2007; SC Chu \& Kim, 2011), then from this conclusion leads to a Hypothesis;

H2: "Informational Influences of consumers as social media users have a significant effect on eWOM on social media"

The motivation for altruism (Altruism) is wanting to put forth effort in caring to help others. This motivation is driven by an empathetic disposition and helps to protect the wellbeing of others. The motivation for consumer altruism is similar to a commitment to people who benefit from one's activities. EWOM communication in its context is activated when consumers want to help other consumers with their purchasing decisions, in the case of positive WOM to activate the same positive experience and in the case of negative WOM to save them from mistakenly purchasing a product to contribute to online information provided through consumer satisfaction with the product or service. In return, the customer wants the company to be or remain successful. After the customer has had a positive experience with the company, they want to return the favor. These two altruistic motives are naturally linked to eWOM actions; therefore, some customers may have this altruistic motive for writing online reviews, but others do not (Reimer \& Benkenstein, 2016), then this conclusion carries a hypothesis;

H3: "Altruism from consumers as social media users have a significant effect on eWOM on social media"

In social networks, people with a high sense of moral obligation are more likely to help others (Goldsmith, Clark, \& Goldsmith, 2006), by sharing their knowledge and experiences with them. Moral awareness of obligations as part of SNSs will encourage 
members to remain in the online community. Because the information has become public property on social media, social media users have a strong moral obligation to share information. When consumers perceive knowledge as a public good, they are motivated to share it with other members because of a sense of moral obligation rather than an expectation of return, this conclusion is hypothetical;

H4: "Moral Obligation from consumers as social media users have a significant effect on eWOM behavior on social media"

B. The effect of eWOM on Purchase Intention

Consumer interest in purchasing certain products and services is indicated as Purchase Intention. Purchase Intention is considered to be the most accurate predictor of actual buying behavior. Consumers browse product reviews and comments of their peers while gathering information and knowledge about products and brands before buying(Jalilvand \& Samiei, 2012; Adjei, Noble, \& Noble, 2010). Consumers usually use eWOM to decide whether they will trust companies in online transactions. Several studies have reported that eWOM presented in seller profiles on online platforms has a marked impact on the closing prices of online auctions(Zhou, Dresner, \& Windle, 2009; Yoo, Ho, \& Tam, 2006; Rice, 2012), which means the significant impact of eWOM on PI online bidders in a virtual context. So, the researcher hopes that eWOM will positively affect Purchase Intention across all online social media platforms so that the hypothesis is as follows;

H5: "There is a positive influence of eWOM on Instagram on Purchase Intention".

So that the research model obtained is as shown in Fig. 3.

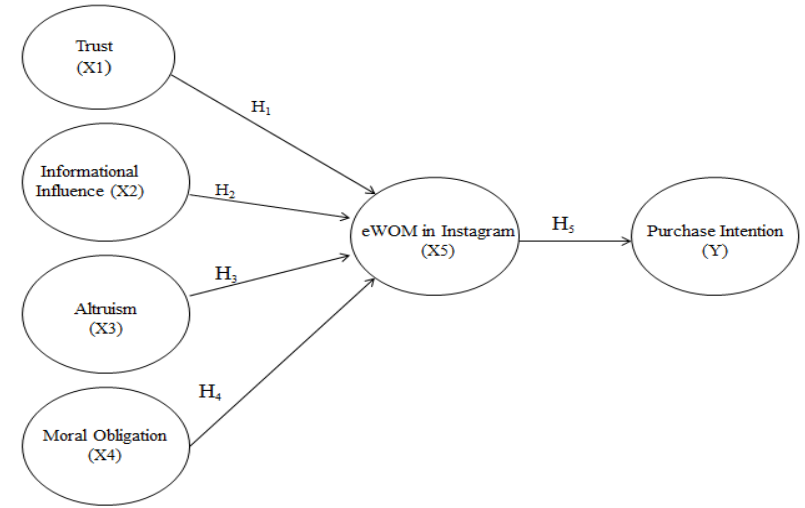

Fig. 3 Research Model on the Effect of Trust, Informational Influence, Altruism, Moral Obligation on eWOM on Purchase Intention

\section{Research Methods}

A. Research Approach

As described in the previous chapter, the main objective of this study is to analyze the pattern of relationships between research variables, so the characteristics used in this study are quantitative descriptive research. According to Sugiyono (2014), the quantitative method is basically a scientific way of obtaining data with specific purposes and uses.

\section{B. Location and Time of Research}

This research was conducted in the city of Batam and its surroundings. As explained in the previous chapter, the purpose of this study is to see whether there is an effect of eWOM through social media Instagram on online product purchase intentions in Batam City. 
The research was carried out from January 2019 to February 2019, during this research period, data collection and processing of survey results and trials and improvements to research instruments were carried out.

C. Population and Sample Research

The number of samples as respondents must be adjusted to the number of question indicators used in the questionnaire, assuming nx 5 observed variables (indicator) up to $\mathrm{nx} 10$ observed variables (indicator). In this study, the number of items was 21 question items used to measure 6 variables, so that the number of respondents used was 21 statement items multiplied by 5 equal to 105 respondents.

D. Data analysis method

This study uses data analysis methods with the SEMPLS version $2.0 \mathrm{~m} 3$ program. SEM-PLS is a variant-based structural equation analysis that can simultaneously evaluate the measurement model as well as the structural model. The use of SEM-PLS analysis allows researchers to combine unobservable variables measured indirectly by indicator variables. (Hair, Sarstedt, Hopkins, \& Kuppelwieser, 2014).

\section{Results and Discussion}

The distribution of respondents based on age, education, gender, and income are presented in Table 1.

Table 1 Characteristics of Respondents Based on Age, Education, Gender, and Income

\begin{tabular}{llll}
\hline Characteristics & & Frequency & Percent \\
\hline Age & $<$ 18 years & 4 & 3.5 \\
& 18-25 years & 103 & 91.2 \\
& 26-36 years & 3 & 2.7 \\
Education & > 36 years & 3 & 2.7 \\
& Elementary School (SD) & 1 & 0.9 \\
& Middle / high school & 44 & 38.9 \\
& D3-S1 & 64 & 56.6 \\
Gender & S2-S3 & 4 & 3.5 \\
Income & Male & 35 & 31 \\
& Women & 78 & 69 \\
& $<$ Rp. 3,000,000 & 38 & 33.6 \\
& IDR 3,000,000-IDR & 61 & 54 \\
& 5,000,000 & & \\
& $>$ IDR 5,000,000 & 14 & 12.4 \\
\hline
\end{tabular}

Source: processed research data, 2019

A. Inferential Analysis

The following is data analysis using the SmartPLS 2.0 program.

B. Outer Model Evaluation (Measurement Model)

There are three characteristics in using data analysis techniques with SmartPLS to assess the outer model, including; 


\section{Convergent Validity}

Furthermore, the results of calculating the AVE value of the research model will be shown in Table 2. Based on the results of the convergent validity test shown in the tables above, it can be explained as follows:

1. The Trust construct is measured by items X1.1- X1.3. It can be seen that there are no items whose loading factor value is $<0.5$ so that all items in the Trust construct are valid and have an AVE value of 0.608018 .

2. The construct of Informational Influence is measured by items X2.1- X2.3. It can be seen that there are no items whose loading factor value is $<0.5$ so that all items in the construct of Informational Influence are valid and have an AVE value of 0.572907 .

3. The Altruism construct is measured by items X3.1- X3.3. It can be seen that there are no items whose loading factor value is $<0.5$ so that all items in the Altruism construct are valid and have an AVE value of 0.659281 .

4. The Moral Obligation construct measured by items X4.1- X4.3 can be seen that there are no items whose loading factor value is $<0.5$ so that all items in the Moral Obligation construct are declared valid and have an AVE value of 0.707991.

5. The eWOM construct is measured by items X5.1- X5.6, it can be seen that there are no items whose loading factor value is $<0.5$ so that all items in the eWOM construct are declared valid and have an AVE value of 0.608018 .

6. The Purchase Intention construct is measured by items Y1.1- Y1.3, it can be seen that there are no items whose loading factor value is $<0.5$ so that all items in Purchase Intention are declared valid and have an AVE value of 0.749323 .

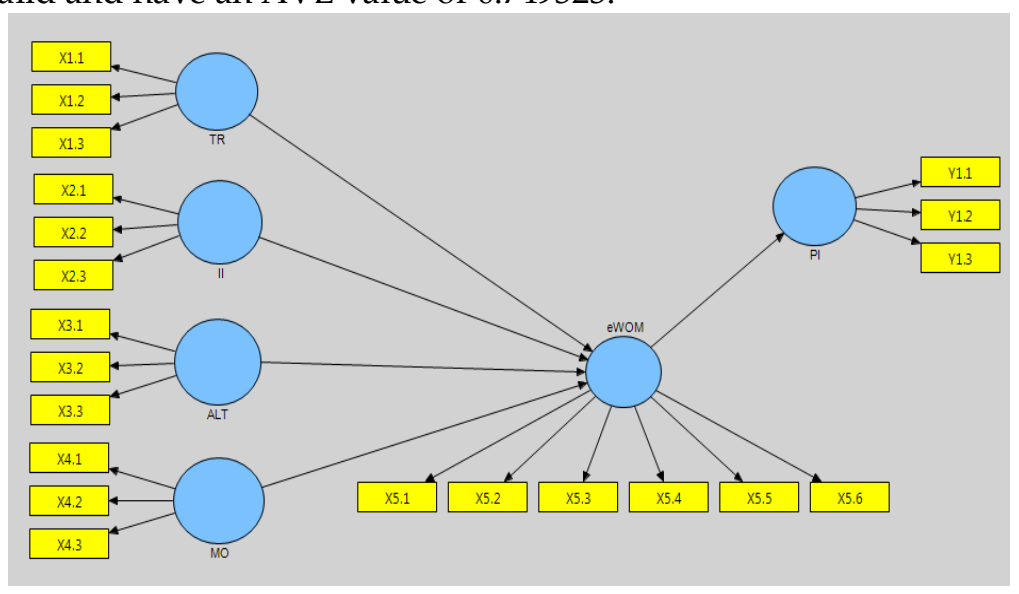

Fig. 4 Research Model Design (Measurement Model)

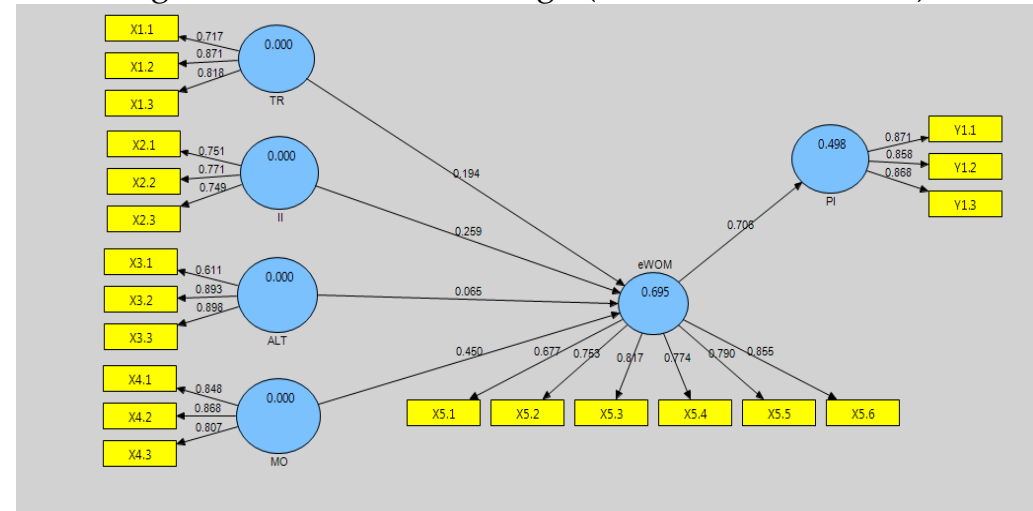

Fig. 5 Output PLS Algorithm Research Model (Measurement Model) Source: processed research data, 2019 
Table 2 AVE Value Research Model

\begin{tabular}{ll}
\hline & AVE \\
\hline ALT & 0.65928 \\
II & 0.57291 \\
MO & 0.70799 \\
PI & 0.74932 \\
TR & 0.64722 \\
eWOM & 0.60802 \\
\hline
\end{tabular}

Source: processed research data, 2019

D. Discriminant Validity

Validity testing for reflective indicators uses a correlation between the item scores and the lantern variable scores. Measurement shows a change in an indicator in a latent variable if other indicators on the same latent variable change (or are removed from the model). Reflective indicators are suitable for measuring perceptions, so this study uses reflective indicators. Reflective indicators need to be tested for discriminant validity by crossloading in Table 3.

Table 3 Value of Cross Loadings Research Model

\begin{tabular}{|c|c|c|c|c|c|c|}
\hline & ALT & II & MO & PI & TR & eWOM \\
\hline X1.1 & & & & & 0.71678 & \\
\hline$X 1.2$ & & & & & 0.87084 & \\
\hline X1.3 & & & & & 0.81825 & \\
\hline X2.1 & & 0.75102 & & & & \\
\hline$X 2.2$ & & 0.77081 & & & & \\
\hline X2.3 & & 0.74869 & & & & \\
\hline X3.1 & 0.61144 & & & & & \\
\hline X3.2 & 0.89329 & & & & & \\
\hline X3.3 & 0.89778 & & & & & \\
\hline X4.1 & & & 0.84798 & & & \\
\hline$X 4.2$ & & & 0.86811 & & & \\
\hline X4.3 & & & 0.80703 & & & \\
\hline X5.1 & & & & & & 0.67717 \\
\hline X5.2 & & & & & & 0.75295 \\
\hline X5.3 & & & & & & 0.8169 \\
\hline X5.4 & & & & & & 0.77439 \\
\hline X5.5 & & & & & & 0.79004 \\
\hline X5.6 & & & & & & 0.85526 \\
\hline Y1.1 & & & & 0.8713 & & \\
\hline Y1.2 & & & & 0.85765 & & \\
\hline Y1.3 & & & & 0.8679 & & \\
\hline
\end{tabular}

Source: processed research data, 2019 
The indicator test is declared valid if the loading value of the variable is the largest compared to other variables. Based on Table 3, it can be concluded that all indicators have a greater correlation coefficient with each construct than the indicator correlation coefficient value in the constructing block in the other columns. Thus it can be concluded that each indicator in the block is the constituent of the construct in the column. It can be seen that the table shows that the loading factor for the Trust indicator (in XI.1 to X1.3) has a higher loading factor compared to other latent variables. The same thing is seen in other indicators. Then the latent construct predicts the indicators on their block better than the indicators of other blocked variables.

There is another method to see the discriminant validity by looking at the square root of the average extracted (AVE) value. The recommended value is above 0.5. Table 4 is a comparison of AVE values in this study.

Table 4 AVE Comparison with AVE Root

\begin{tabular}{lcc}
\hline \multicolumn{1}{c}{ Construct } & AVE & AVE root \\
\hline ALT & 0.659281 & 0.8112 \\
II & 0.572907 & 0.7569 \\
MO & 0.707991 & 0.8414 \\
PI & 0.749323 & 0.8656 \\
TR & 0.647221 & 0.8045 \\
eWOM & 0.608018 & 0.7798 \\
\hline
\end{tabular}

Table 5 Research Model Latent Variable Correlation

\begin{tabular}{lcccccc}
\hline & ALT & II & MO & PI & TR & eWOM \\
\hline ALT & 1 & & & & & \\
II & 0.63137 & 1 & & & & \\
MO & 0.72638 & 0.64154 & 1 & & & \\
PI & 0.467 & 0.59674 & 0.49495 & 1 & & \\
TR & 0.50192 & 0.59537 & 0.56257 & 0.6291 & 1 & \\
eWOM & 0.65256 & 0.70431 & 0.77232 & 0.70573 & 0.63404 & 1 \\
\hline
\end{tabular}

Source: processed research data, 2019

Based on Table 4 the AVE Root, and Table 5 the correlation of the latent variables of the research model it can be explained that the AVE Root for the ALT construct is 0.81196 , while the maximum correlation between ALT and other constructs is 0.659281 so that the AVE root value of the ALT extract is greater than the correlation value of other constructs. This shows that other discriminant validity requirements are met. Likewise with other constructs that show the AVE root is greater than the correlation construct. The AVE value that appears to be greater than 0.5 is overall the latent variable contained in the research model. The lowest AVE value is in the latent informational influence variable with a value of 0.572907 .

\section{E. Composite Reliability}

The reliability test is done by looking at the composite reliability value of the indicator block that measures latent variables. The results of composite reliability will show good value if it is greater than 0.7. Table 6 is composite reliability values. 


\begin{tabular}{lc}
\multicolumn{2}{c}{ Table 6 Composite Reliability value } \\
\hline ALT & Composite Reliability \\
II & 0.849555 \\
MO & 0.800937 \\
PI & 0.879037 \\
TR & 0.899671 \\
eWOM & 0.84542 \\
\hline \multicolumn{2}{c}{ Source: processed research data, 2019 }
\end{tabular}

Table 6 shows that all constructs have a composite reliability value above 0.7 so that all latent variables in the model meet the criteria. The lowest composite reliability value is 0.800937 on the latent variable Informational Influence. Therefore, there is no problem with reliability/unidimensionality in the formed model.

The reliability test can also be strengthened with Cronbach's Alpha as shown in Table 7. The suggested value is above 0.6 and the Cronbach's Alpha Table 7 shows that the lowest value is 0.628277 (Informational Influence).

Table 7 Cronbach's Alpha

\begin{tabular}{lc}
\hline & Cronbach's Alpha \\
\hline ALT & 0.72511 \\
II & 0.628277 \\
MO & 0.793472 \\
PI & 0.832984 \\
TR & 0.729682 \\
eWOM & 0.870037 \\
\hline
\end{tabular}

Source: processed research data, 2019

F. Evaluation of the Structural Model (Inner Model)

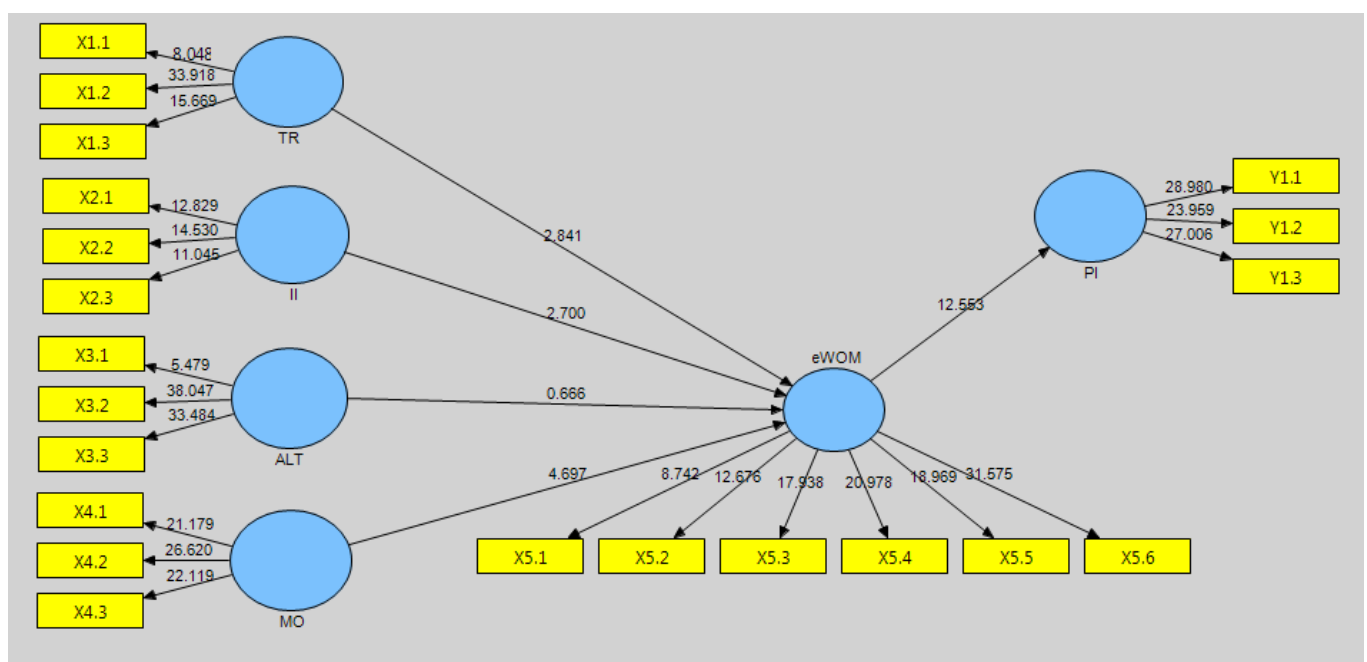

Fig. 6 PLS Bootstrapping Research Model Output 
Testing of the structural model (Inner Model) is carried out after the estimated model meets the Outer Model criteria, then testing the structural model (inner model) by performing the R-Square test. The estimation results of R-square using PLS can be seen in Table 8.

\begin{tabular}{cc}
\multicolumn{3}{l}{ Table 8 Value of R Square } \\
\hline PI & R Square \\
eWOM & 0.49805 \\
\multicolumn{2}{l}{ Source: processed research data, 2019}
\end{tabular}

The value of $R$ Square (R2) shows the level of determination of the exogenous variables towards the endogenous. The bigger the $\mathrm{R} 2$ value indicates a better level of determination. As expressed by Chinn, (1998) that the R square results are 0.67 (strong), 0.33 (moderate), and 0.19 (weak).

Table 8 provides a value of 0.498054 for the latent variable Purchase Intention which is able to explain the eWOM variance of $49.8054 \%$. The $\mathrm{R}$ Square value is also found in eWOM which is influenced by PI, which is 0.695309, namely that the results of the endogenous variables are strong.

\section{G. Hypothesis test}

Hypothesis Testing to find out whether the hypothesis will be accepted or rejected. If the $\mathrm{t}$-statistic value>t-table, then the hypothesis will be accepted. The T-statistic value that is commonly used for the test is 1.96 (with a significance level of $=5 \%$ ). In marketing, researchers usually assume a significance level of $5 \%$ but do not rule out other significance levels. The results of the t-statistic estimation, which can be seen in Table 9 .

H. The hypothesis of the Effect of Trust, Informational Influence, Altruism and Moral Obligation on eWOM

Table 9 Hypothesis Testing the Effects of TR, II, ALT, and MO on eWOM

\begin{tabular}{rccccc}
\hline & $\begin{array}{c}\text { Original } \\
\text { Sample (O) }\end{array}$ & $\begin{array}{c}\text { Sample } \\
\text { Mean (M) }\end{array}$ & $\begin{array}{c}\text { Standard } \\
\text { Deviation } \\
\text { (STDEV) }\end{array}$ & $\begin{array}{c}\text { Standard Error } \\
\text { (STERR) }\end{array}$ & $\begin{array}{c}\text { T Statistics } \\
\text { ( I O / } \\
\text { STERR I) }\end{array}$ \\
\hline ALT -> & & & & & \\
eWOM & 0.064702 & 0.055122 & 0.106859 & 0.106859 & 0.605486 \\
II -> eWOM & 0.259363 & 0.276179 & 0.100049 & 0.100049 & 2,592354 \\
MO -> eWOM & 0.449699 & 0.443273 & 0.095353 & 0.095353 & 4.716165 \\
TR -> eWOM & 0.194159 & 0.197174 & 0.067730 & 0.067730 & 2.866673 \\
\hline
\end{tabular}

Source: processed research data, 2019

Hypothesis testing for each of the latent variable relationships is shown in Table 9.

a) Table 9 shows that the relationship between altruism and eWOM is not significant with a t-statistic of 0.605486 , because it is smaller than 1.96 . Thus the hypothesis in this study states that 'Altruism from consumers as social media users have a significant effect on eWOM on social media' rejected. 
b) The relationship between informational influence and eWOM is significant with a tstatistic of 2.592354 (> 1.96). The original sample estimate value is positive, namely 0.259363 which indicates that the direction of the relationship between informational influence and eWOM is positive. Thus the hypothesis in this study states that 'Informational Influences of consumers as social media users have a significant effect on eWOM on social media' be accepted.

c) Table 9 also shows that the relationship between moral obligation and eWOM is significant with a t-statistic of 4.716165 (> 1.96). The original sample estimate value is positive, namely 0.449699 which indicates that the direction of the relationship between moral obligation and eWOM is positive. Thus the hypothesis in this study states that 'Moral Obligation from consumers as social media users have a significant effect on eWOM behavior on social media' be accepted.

d) Table 9 also shows that the relationship between trust and eWOM is significant with a tstatistic of $2.866673(>1.96)$. The original sample estimate value is positive, which is 0.194169 which indicates that the direction of the relationship between trust and eWOM is positive. Thus the hypothesis in this study states that 'Trust of consumers as social media users have a significant effect on eWOM on social media ' be accepted.

I. The hypothesis of the Effect of eWOM on Purchase Intention

Table 10 Hypothesis of the effect of eWOM on PI

\begin{tabular}{lccccc}
\hline & $\begin{array}{c}\text { Original } \\
\text { Sample (O) }\end{array}$ & $\begin{array}{c}\text { Sample } \\
\text { Mean (M) }\end{array}$ & $\begin{array}{c}\text { Standard } \\
\text { Deviation } \\
\text { (STDEV) }\end{array}$ & $\begin{array}{c}\text { Standard Error } \\
\text { (STERR) }\end{array}$ & $\begin{array}{c}\text { T Statistics ( I } \\
\text { O / STERR I) }\end{array}$ \\
\hline Ewom $>$ PI & 0.705729 & 0.704876 & 0.059972 & 0.059972 & 11,767738 \\
\hline
\end{tabular}

Source: processed research data, 2019

The hypothesis of the effect of eWOM on purchase intention, which can be seen in Table 10 shows that the relationship between eWOM and purchase intention is significant with a t-statistic of 11,767738 ( $>1.96)$. The original sample estimate value is positive, namely 0.705729 which indicates that the direction of the relationship between eWOM and purchase intention is positive. Thus the hypothesis in this study states that 'There is a positive effect of eWOM on Instagram on Purchase Intention' be accepted.

\section{Research Implications}

Theoretically, the research results found have explained that the research proves empirically, it is known that eWOM has a positive and significant effect on online purchase intention of products. This result is expected to be a reference basis and a reference for the formation of new theories for further research related to eWOM in its relation to purchasing intention.

Globalization at this time has made changes in human civilization more dynamic and fast in all aspects of life. The impact of globalization is that the development of information technology is increasingly accelerating all the time. Likewise with the increasingly fierce and competitive competition. Conditions like this cause an organization to have new methods to respond to everything that will happen to survive. (Silalahi \& Sundiman, 2016). The development of eWOM theory is recognized as an effective marketing strategy as a place to promote products. The use of internet technology on social media creates opportunities for 
consumers to access various types of information through eWOM which are provided to different people (Wang, Wang, \& Wang, 2018).

The practical implications of the results of this study are expected to be used as input in online marketing through social media Instagram with the advantages of promoting products online and engaging with target customers. With the findings from this research, it can help online marketing parties through Instagram social media to develop new methods of spreading their products through the Instagram social media network. This research can also be useful for building positive perceptions about products and services because a positive eWOM will consequently affect purchase interest. Therefore, a marketing practitioner needs to focus on activating consumer engagement. Marketing practitioners can improve their marketing strategy by using social media to increase the number of customers who intend to buy a product online. Moreover, with the development of technology, MSEs as practitioners in developing their marketing need to adjust, especially in the marketing process. Marketing through digital by utilizing social media, social chatting, marketplaces, and the use of other platforms makes it easier for MSEs to be able to attract and interact directly with consumers (Febriyantoro \& Arisandi, 2018).

Indonesia is a country that has a variety of cultural riches in the world and this condition will certainly be an opportunity to take a big risk and challenge for SMEs in Indonesia by taking advantage of existing conditions to make various variations of the best management for the economy, social and geographical in each region. (Sundiman, Chien, Andi, Surya, \& Asmara, 2019) .San SME will produce more innovation in business if it focuses more on creating knowledge from the innovation itself and how they are able to properly convey (transfer) this knowledge which is then transformed into innovation in SMEs (Rumiyati \& Sundiman, 2017).

Rapid market changes due to globalization and technological advances encourage organizations to adapt quickly. Organizations must continue to improve their strategic policies (Sundiman, 2018). The researcher's findings indicate that marketing practitioners should try to identify the market, encourage social media account users to engage in positive eWOM, and prevent the spread of negative consumer eWOM by sharing their difficult experiences with a product. In addition, social media enables marketing practitioners and has access to a large number of consumers at high speed and low cost. This further allows marketing practitioners to adopt a personalized and tailored marketing strategy for the target consumers of the company's products and brands to meet the needs of social media users especially Instagram.

\section{Conclusion}

Based on the results of data processing and analysis as well as a discussion of "The influence of eWOM through Instagram social media on purchase intention of products online in Batam City", it can be concluded that electronic word of mouth (eWOM) through Instagram social media has a significant effect on product purchase intention. online in Batam City, which means that eWOM through Instagram social media has a positive effect in influencing purchase intention of online products in Batam City. Based on the data obtained from distributing questionnaires to respondents, overall respondents have a high perception of the eWOM variable reflected in the magnitude of the total average value of 2.882 (interval 2.50-3.24). The total average can be concluded that the respondents are at most in number 3 on the eWOM variable. 
Besides that, eWOM consists of several variables whose results can be concluded that:

1) Altruism not significant to electronic word of mouth (eWOM) through social media Instagram, which means that the nature of altruism has a negative effect in influencing eWOM through social media Instagram even though the overall average value is 2,885 (interval 2.50-3.24).

2) Informational influence significant towards eWOM through social media Instagram, which means that informational influence has a positive effect on influencing eWOM through Instagram social media. Based on the data obtained from distributing questionnaires to respondents, overall respondents have a high perception of the informational influence variable as reflected in the magnitude of the total average value of2,935 (interval 2.503.24). From this total average, it can be concluded that the respondents are mostly in number 3 on the informational influence variable.

3) Moral Obligation significant to eWOM through the social media Instagram which means Moral Obligation (moral obligation) has a positive effect in influencing eWOM through Instagram social media. Based on the data obtained from distributing questionnaires to respondents, overall respondents have a high perception of the moral obligation variable as reflected in the magnitude of the total average value of2,985 (interval 2.50-3.24). It can be concluded that the total number of respondents is 3 on the moral obligation variable.

4) Trust significantly to eWOM through the social media Instagram which means trust (trust) has a positive effect in influencing eWOM through Instagram social media. Based on the data obtained from distributing questionnaires to respondents, overall respondents have a high perception of the trust variable is reflected in the magnitude of the total average value of 2,885 (interval 2.50-3.24). The total average can be concluded that the respondents are at most in number 3 on the trust variable.

Based on the results of the research, discussion, and conclusions obtained, the following suggestions can be given:

1) Social media (especially Instagram) cannot be used as the only media to spread eWOM and is not a guarantee to generate consumer buying interest. However, the use of social media also determines consumer buying interest because eWOM is a relatively new phenomenon and still needs to be deepened a lot.

2) The next researcher can develop this research by examining other factors that can influence purchase intention.

3) It is recommended that the sample used to be reproduced so that the research results are more accurate.

4) For product marketing, it is advisable to continue to increase consumer engagement by utilizing features on Instagram social media, such as interestingly conveying information.

\section{References}

Adjei, M. T., Noble, S. M., \& Noble, C. H. (2010). The influence of C2C communications in online brand communities on customer purchase behavior. Journal of the Academy of Marketing Science, 38(5), 634-653. https://doi.org/10.1007/s11747-009-0178-5

APJII. (2017). Penetrasi \& Perilaku Pengguna Internet Indonesia, 2018(31 August 2018), Hasil Survey.

Batamnews. (2018). Belanja Online Meningkat, Pendapatan Jasa Kurir Berlipat. Retrieved from https://www.batamnews.co.id/berita-35039-belanja-online-meningkat-pendapatanjasa-kurir-berlipat.html 
Batamnews.co.id. (2018). Transaksi Online Tinggi di Batam, Pengiriman Barang Banyak Tertunda. Retrieved from https://www.batamnews.co.id/berita-35038-transaksi-online-tinggi-dibatam-pengiriman-barang-banyak-tertunda.html

Bohang, F. K. (2017). Indonesia, Pengguna Instagram Terbesar se-Asia Pasifik. Retrieved from https://tekno.kompas.com/read/2017/07/27/11480087/indonesia-pengguna-instagramterbesar-se-asia-pasifik

Chinn, W. W. (1998). The Partial Least Squares Approach to Structural Equation Modelling. Modern Methods for Business Research, 29(2), 295-336.

Chu, S. C., \& Kim, Y. (2011). Determinants of consumer engagement in electronic Word-OfMouth (eWOM) in social networking sites. International Journal of Advertising, 30(1), 37-41. https://doi.org/10.2501/IJA-30-1-047-075

Chu, S.-C., \& Kim, Y. (2011). Determinants of consumer engagement in electronic word-ofmouth in social networking sites. International Journal of Advertising, 30(1), 47-75.

F. Hair Jr, J., Sarstedt, M., Hopkins, L., \& G. Kuppelwieser, V. (2014). Partial least squares structural equation modeling (PLS-SEM). European Business Review, 26. https://doi.org/10.1108/EBR-10-2013-0128

Farzin, M., \& Fattahi, M. (2018). eWOM through social networking sites and impact on purchase intention and brand image in Iran. Journal of Advances in Management Research, JAMR-05-2017-0062. https://doi.org/10.1108/JAMR-05-2017-0062

Febriyantoro, M. T., \& Arisandi, D. (2018). Pemanfaatan Digital Marketing Bagi Usaha Mikro, Kecil Dan Menengah Pada Era Masyarakat Ekonomi Asean. JMD: Jurnal Manajemen Dewantara, 1(2), 61-76.

Goldsmith, R. E., Clark, R. A., \& Goldsmith, E. B. (2006). Extending the psychological profile of market mavenism. Journal of Consumer Behaviour, 5(5), 411-419. https://doi.org/10.1002/cb

Huang, J. H., Hsiao, T. T., \& Chen, Y. F. (2012). The Effects of Electronic Word of Mouth on Product Judgment and Choice: The Moderating Role of the Sense of Virtual Community. Journal of Applied Social Psychology, 42(9), 2326-2347. https://doi.org/10.1111/j.1559-1816.2012.00943.x

Jalilvand, M. R., \& Samiei, N. (2012). The effect of electronic word of mouth on brand image and purchase intention: An empirical study in the automobile industry in Iran. Marketing Intelligence and Planning, 30(4), 460-476. https://doi.org/10.1108/02634501211231946

Kemp, S. (2018). Digital in 2018: World's Internet Users Pass the 4 Billion Mark. Retrieved from https://wearesocial.com/blog/2018/01/global-digital-report-2018

Kunja, S. R., \& GVRK, A. (2018). Examining the effect of eWOM on the customer purchase intention through value co-creation (VCC) in social networking sites (SNSs). Management Research Review, (Vcc), MRR-04-2017-0128. https://doi.org/10.1108/MRR04-2017-0128

Mangold, W. G., \& Faulds, D. J. (2009). Social media: The new hybrid element of the promotion mix Social media: The new hybrid element of the promotion mix. Business Horizons, (52), 357-365. https://doi.org/10.1016/j.bushor.2009.03.002

Muk, A. (2007). Consumers' intentions to opt in to SMS advertising: A cross-national study of young Americans and Koreans. International Journal of Advertising, 26(2), 177-198. https://doi.org/10.1080/10803548.2007.11073006

Reimer, T., \& Benkenstein, M. (2016). Altruistic eWOM marketing: More than an alternative to monetary incentives. Journal of Retailing and Consumer Services, 31, 323-333. https://doi.org/10.1016/j.jretconser.2016.04.003 
Rice, S. C. (2012). Reputation and uncertainty in online markets: An experimental study. Information Systems Research, 23(2), 436-452. https://doi.org/10.1287/isre.1110.0362

Ridings, C. M., Gefen, D., \& Arinze, B. (2002). Some antecedents and effects of trust in virtual communities. Journal of Strategic Information Systems, 11(3-4), 271-295. https://doi.org/10.1016/S0963-8687(02)00021-5

Rumiyati, \& Sundiman, D. (2017). No Title. Peran Manajemen Pengetahuan Pada Kapasitas Unovasi Usaha Kecil Dan Menengah (UKM) (Studi Pada UKM Di Kota Sampit), 2(2), 136148

Silalahi, H. C., \& Sundiman, D. (2016). Knowledge Sharing Sebagai Sumber Inovasi Dan Keunggulan Bersaing Pada Usaha Kecil Menengah (UKM) Sektor Bengkel Otomotif (Studi Kasus CV. Ariron Jaya Tehnik). E-Jurnal Profit (Jurnal Penerapan Ilmu Manajemen Dan Kewirausahaan), 3(1), 56. https://doi.org/https://doi.org/10.3929/ethz-b000238666

Sugiyono. (2014). Metode Penelitian Pendidikan Pendekatan Kuantitatif, Kualitatif dan RED. https://doi.org/10.1007/s13398-014-0173-7.2

Sundiman, D. (2018). The Effect Of Knowledge Management on The Strategic Mangement Process Media by Competitive Intelligence in The Small Business Company. Jurnal Manajemen Dan Kewirausahaan, 20(2), 105-115. https://doi.org/10.9744/jmk.20.2.105

Sundiman, D., Chien, H. W., Andi, M., Surya, B. P. J., \& Asmara, I. (2019). Knowledge management key factors: an empirical research on small and medium-sized enterprises in Indonesia. International Journal Business and Systems Research, 13(2), 139161.

Wang, J. J., Wang, L. Y., \& Wang, M. M. (2018). Understanding the effects of eWOM social ties on purchase intentions: A moderated mediation investigation. Electronic Commerce Research and Applications, 28, 54-62. https://doi.org/10.1016/j.elerap.2018.01.011

Yoo, B., Ho, K., \& Tam, K. Y. (2006). The impact of information in electronic auctions: An analysis of buy-it-now auctions. In Proceedings of the Annual Hawaii International Conference on System Sciences (Vol. 8). https://doi.org/10.1109/HICSS.2006.470

Zhou, M., Dresner, M., \& Windle, R. (2009). Revisiting feedback systems: Trust building in digital markets. Information and Management, 46(5), 279-284. https://doi.org/10.1016/j.im.2009.05.002. 